Discussion Paper No. 10-061

\title{
Individual Adaptation to Climate Change: The Role of Information and Perceived Risk
}

Daniel Osberghaus, Elyssa Finkel, and Max Pohl

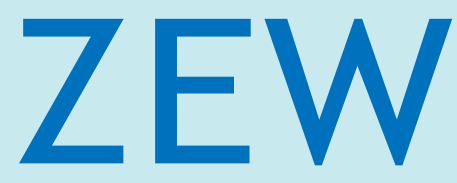

Zentrum für Europäische Wirtschaftsforschung $\mathrm{GmbH}$

Centre for European Economic Research 
Discussion Paper No. 10-061

\title{
Individual Adaptation to Climate Change: The Role of Information and Perceived Risk
}

\author{
Daniel Osberghaus, Elyssa Finkel, \\ and Max Pohl
}

Download this ZEW Discussion Paper from our ftp server:

ftp://ftp.zew.de/pub/zew-docs/dp/dp10061.pdf

Die Discussion Papers dienen einer möglichst schnellen Verbreitung von neueren Forschungsarbeiten des ZEW. Die Beiträge liegen in alleiniger Verantwortung der Autoren und stellen nicht notwendigerweise die Meinung des ZEW dar.

Discussion Papers are intended to make results of ZEW research promptly available to other economists in order to encourage discussion and suggestions for revisions. The authors are solely responsible for the contents which do not necessarily represent the opinion of the ZEW. 


\section{Non-technical Summary}

Climate change is seen as a problem facing current and future generations. Two measures exist in order to cope with its potential effects: mitigation and adaptation. Mitigation describes all measures which aim to reduce human based influences on the climate, namely $\mathrm{CO}_{2}$ and other greenhouse gas emissions. On the contrary, adaptation entails all adjustments in response to actual or expected effects of climate change which serve to reduce harm or exploit potential benefits. While mitigation has been the focus of scientific and political discussions in the past decades, adaptation may become increasingly important as some of the effects of climate change are impending and already irreversible. From an economic point of view, adaptation, contrary to most mitigation options, can also be rational for individuals as they may come to the conclusion that is in their own interest to adapt to new environmental conditions.

This study aims to shed light onto some of the factors supporting or hindering individual engagement in adaptation behavior, which little research has empirically investigated to date. In order to analyze behavioral change with regard to climate change, this paper takes on a broader perspective of adaptation, which can be defined as all changes an individual makes in order to adjust to a changing environment. In particular, the effect of information on the perceived risk of individuals was investigated, drawing on a psychological framework called Protection Motivation Theory. Three hypotheses were constructed which were empirically tested in the study: (i) higher levels of perceived risk lead to higher levels of motivation to adapt; (ii) providing information as opposed to not providing information increases perceived risk; (iii) providing locally-focused information as opposed to globally-focused information leads to higher levels of perceived risk.

It was found that higher perceived risk did lead to significantly higher motivation to adapt, giving support to hypothesis one. However, hypothesis two and three could not be supported, as the effects of information (compared to no information), and locally-focused information (compared to globally-focused information) on perceived risk were not significant. These results suggest that, contrary to the assumptions in economic theory, the sole provision of information is not sufficient to spur motivation to adapt. A range of potential variables which may have an influence on these effects are discussed, including the comparably mild climate change effects in the study region and the lack of concrete behavioral advice. 


\section{Das Wichtigste in Kürze}

In der Klimapolitik gibt es zwei grundlegende Handlungsstränge - Vermeidung und Anpassung. Vermeidung beschreibt alle Maßnahmen, die den menschlichen Einfluss auf das Klima verringern sollen, z.B. die Reduzierung von Treibhausgasemissionen. Anpassung beinhaltet dagegen die Reaktion auf die beobachtbaren oder erwarteten Auswirkungen des Klimawandels, um Schäden zu verringern oder potenzielle Vorteile zu nutzen. Aus ökonomischer Sicht kann Anpassung, im Gegensatz zu den meisten Vermeidungsmaßnahmen, auch für den Einzelnen eine rationale Verhaltensweise darstellen, wenn er zu der Schlussfolgerung kommt, dass eine Anpassung an neue Umweltbedingungen im eigenen Interesse ist.

Diese Studie untersucht wichtige Faktoren, die individuelle Anpassungsentscheidungen beeinflussen - ein Themenfeld, das in der empirischen Literatur bisher noch unzureichend behandelt wurde. Hierfür wird eine sozialwissenschaftliche Perspektive des Anpassungsbegriffs gewählt. Demnach werden alle Verhaltensänderungen eines Individuums in Reaktion auf ein sich wandelndes Umfeld als Anpassung definiert.

Aufbauend auf dem psychologischen Model der Schutzmotivationstheorie wird speziell der Einfluss von Informationen auf das wahrgenommene Risiko von Individuen untersucht. Im Rahmen der Studie werden drei Hypothesen empirisch untersucht: (1) ein höheres wahrgenommenes Risiko führt zu einer höheren Motivation zur Anpassung, (2) die Bereitstellung von Information über erwartete Klimaschäden erhöht das wahrgenommene Risiko, (3) Informationen mit einem lokalen Fokus führen, verglichen mit Informationen mit einem globalen Fokus, zu einem höheren wahrgenommenen Risiko.

Die erhobenen Daten zeigen, dass ein höheres wahrgenommenes Risiko zu einer signifikant höheren Motivation zur Anpassung führt und unterstützen damit Hypothese 1. Allerdings werden Hypothese 2 und 3 nicht unterstützt - die Effekte von Information (verglichen mit keiner Information) und lokal fokussierter Information (verglichen mit global fokussierter Information) auf das wahrgenommene Risiko sind nicht signifikant. Diese Ergebnisse deuten darauf hin, dass entgegen den Annahmen der ökonomischen Theorie die alleinige Bereitstellung von Information nicht ausreicht, um die Motivation zur Anpassung ausreichend zu steigern. Eine Reihe von Variablen, die einen Einfluss auf das wahrgenommene Risiko haben können, werden abschließend diskutiert, darunter die vergleichsweise milden Klimawandeleffekte innerhalb der Studienregion sowie das Fehlen konkreter Hinweise auf mögliche Verhaltensänderungen innerhalb der kommunizierten Information. 


\title{
Individual Adaptation to Climate Change: The Role of Information and Perceived Risk
}

\author{
Daniel Osberghaus ${ }^{\mathrm{a}}$, Elyssa Finkel, and Max Pohl \\ Department of Environmental and Resource Economics, Environmental Management, Centre for European \\ Economic Research, L 7, 168161 Mannheim, Germany
}

July 2010

\begin{abstract}
Given that many of the predicted effects of climate change are considered imminent and unavoidable, the need to mainstream adaptation as a viable coping measure among private households is becoming a topic of increasing importance. However, little research to date has assessed the factors influencing the motivation to autonomously adapt, nor any successful measures for instigating this behavioural change. This study investigates whether providing locally-focused vs. globally-focused information about the effects of climate change influences the personal perceived risk (PPR) of individual people. Based on a socio-psychological model, Protection Motivation Theory (PMT), it is hypothesized that a higher PPR will lead to a higher motivation to adapt. While this hypothesis has been empirically confirmed by the study, it has been found that providing information on climate change effects that is more personally relevant to the individual and is concerned with his local surroundings does not significantly increase PPR. This may be due to a trade-off between spatial-temporal distance and the comparably low severity of predicted effects in the study region. Interestingly, providing any kind of information, irrespective of having a global or local focus, also did not increase PPR as compared to receiving no information. These results suggest that the sole provision of information about expected climate change impacts, even if tailored to one's individual context, does not significantly increase PPR and consequently the motivation to adapt. Another necessary factor might be increasing the knowledge about concrete coping options to allow people to weigh up their personal options.
\end{abstract}

Keywords: individual adaptation, perceived risk, adaptation motivation, spatial-temporal distance, information, protection motivation theory

JEL-Classification: Q54, Q58, D83

Acknowledgements: We would like to thank our colleagues of the Department for Environmental and Resource Economics, Environmental Management, in particular Astrid Dannenberg, Andreas Löschel and Tim Mennel for their inspiration and valuable input during the design and analysis of this paper.

\footnotetext{
${ }^{\text {a }}$ Corresponding author. Tel: +49 (0)621 1235-205; Fax: +49 (0)621 1235-226.

Email addresses: osberghaus@zew.de (D. Osberghaus), f-pohl@zew.de (M.Pohl),p-finkel@zew.de (E. Finkel)
} 


\section{Introduction}

Climate change is widely recognized as a major challenge facing the world today and increasingly in the coming decades. Two chief coping strategies can be identified: societies can either try to decelerate or stop climate change by reducing emissions (mitigation), or they can attempt to adapt to the new conditions (adaptation). Mitigation has generally been the focus of scientific and political discussions in the past years, while adaptation has only recently gained increased attention. As shown by the outcomes of the recent international climate summit in Copenhagen in 2009, the potential for free riding effects among countries still causes doubt whether an international agreement on binding emission reduction targets can indeed be achieved. Consequently, adaptation may become increasingly important in the near future.

The Intergovernmental Panel on Climate Change (IPCC) defines adaptation as the "adjustment in natural or human systems in response to actual or expected climatic stimuli or their effects which moderates harm or exploits beneficial opportunities" (IPCC, 2007b, p. 869). Importantly, adaptation differs from mitigation in the following: (i) it will in most cases provide local benefits, and (ii) these benefits will be typically realized with shorter time lags (Stern 2007). Adger (2001) supports the first point in suggesting that mitigation is a measure that takes place at the global scale, whereas adaptation can occur at various levels, from local to global. While global adaptation mainly refers to the enhancement of adaptive capacity (e.g. financing of global adaptation funds, education in developing countries), most if not all direct adaptation measures can be found at the local level (Tol, 2005). Consequently and in contrary to mitigation, there is the possibility of private provision of adaptation - to the extent that adaptation constitutes a private good.

While the definition of adaptation in an economic context refers to an adjustment in response to climate change effects that is deliberately supposed to moderate harm and exploit benefits, the term arises in a variety of fields from evolutionary biology to political ecology (e.g. Smit and Wandel, 2006) and can also be understood in a broader sense, referring to all measures that are taken in order to adjust to new environmental conditions. This broader definition disregards the specific intention to ameliorate climate damages and capitalize on benefits. If this broader definition of adaptation is applied, many coping measures may be included which are otherwise considered as mitigation measures. In order to illustrate this distinction, think about an individual living next to a river and expecting an increasing risk of flooding in the near 
future. The individually motivated decision to take an insurance against flood damages for his property can be clearly considered as an adaptation measure. On the contrary, an individual deciding to travel by train rather than flying in order to reduce his personal emissions is considered a mitigation measure in the light of the current definition of the IPCC. However, when a broader definition is applied, as in the current study, both behaviors can be regarded as a behavioral adaptation to a changed environment.

In the economic literature, two types of adaptation with regard to the relevant actors are distinguished: (i) autonomous adaptation, motivated by the private, utility-maximizing paradigm of firms and individuals, and (ii) planned adaptation, based on collective action and mostly initiated by governmental entities. Autonomous adaptation occurs as individuals naturally respond to the market and physical environment or other circumstances they face. It can also be described as a behavioral response to an environmental change that is mainly for one's own benefit (Mendelsohn, 2000). Planned adaptation on the other hand is the result of a strategic policy decision for the sustainable benefit of a society. ${ }^{1}$ However, in this paper we focus on autonomous adaptation of private households and how to enhance autonomous adaptation by supplying information.

Familiarity with adaptation as a coping strategy has yet to be more assimilated into the public's current understanding and knowledge about climate change issues. Although visible changes in climate, including severe storms and floods, appear to be occurring at an increasing rate, concern about climate change does not seem to be translating into a considerable amount of adaptive responses (e.g. Leiserowitz, 2007). One of the reasons might be that most adaptation measures have a precautionary or proactive character, i.e. they will be taken prior to an event, such as investing in infrastructure to protect against floods, and thus require foresight and careful consideration of risks, benefits and costs. This is where information takes on a crucial role. One important goal of planned adaptation is the dissemination of information about regional climate change impacts (Dannenberg et al., in press). Adaptation policy by the way of information dissemination would naturally aim to enhance precautionary adaptation of private actors. Accordingly, insufficient information may lead to a lack of adaptive responses. The importance of information also becomes clear in Stern (2007), where adaptation policy is

\footnotetext{
${ }^{1}$ It should be noted, that in spite of the wording "autonomous" vs. "planned", autonomous adaptation may indeed follow a deliberate plan (just take the example of a private power plant investor, anticipating less cooling water availability in the next decades). The main characteristic behind autonomous adaptation is the private motivation of the respective actors. Regarding planned adaptation, see Dannenberg et al. (in press) for a detailed analysis of the role of the government in adaptation.
} 
divided in two main strands: (i) building adaptive capacity through the dissemination of information and the creation of conditions needed to support adaptation and (ii) delivering adaptation in cases where autonomous adaptation fails to take place.

However, the high level of uncertainty about the nature and timing of climate change impacts certainly acts as a hindrance to the goal of enhancing autonomous adaptation. It is a widely observed, global phenomenon that people living in natural disaster prone areas do not take sufficient precautionary measures to ameliorate the possible effects of such an event on their daily lives (Kunreuther, 1996). So, the question arises what are the factors and barriers that influence people's decision to adapt to climate change and hence to change their behavior? What possible strategies can be adopted to prompt people to overcome these barriers and to increase motivation for action? These questions broadly define the motivation behind the present study.

Accordingly, the broader definition of adaptation introduced earlier becomes important in the context of this study, since this research analyzes the process by which an individual changes his or her behavior in adapting to a new environment, irrespective of the specific adaptive intention. Understanding the motives and methods by which this behavioral change occurs is nevertheless important for implementing future adaptation measures in an economic sense. In particular, this study examines the effect of providing information about climate change effects tailored to the local environment of survey participants versus providing them only with more general, globally relevant facts and predictions. This distinction is a recurrent theme in the literature about the design of information campaigns and future adaptation strategies (World Development Report, 2010; Adger et al., 2009; Moser and Dilling, 2004; Klein et al., 1999; Smit and Pilifosova, 2003; Smit and Wandel, 2006). Furthermore, this study builds on the psychological theory of 'protection motivation' (PMT) (Rogers, 1983; Rogers and Prentice-Dunn, 1997) and its recent application to climate change (Grothmann and Reusswig, 2006). We focus on the context of a developed country, although some of the findings may also be helpful for designing information campaigns in the developing world.

\section{Psychological perspective of adaptation}

So far, little attention has been given to the role of psychological barriers in adaptation to climate change. Since a large part of adaptation relies on the actions carried out by individuals in 
their local environments, it seems important to consider how psychological factors may influence adaptive action. According to the World Development Report (2010), understanding the drivers of human behavior is essential for climate-smart development policy. Further on, adaptation to climate change is an example of human decision-making under uncertainty (Grothmann and Patt, 2005). Similar situations involving human decision-making have been well-researched in the psychological literature and demonstrate that beside socio-economic determinants psychological factors such as motivation and perceived abilities must be considered in order to accurately predict future action.

Two case studies carried out by Grothmann and Patt (2005) are among the few that look decidedly into cognitive factors affecting adaptive capacity. Both cases look into the use of proactive adaptation measures, one in Germany to the risk of river flooding and the other in Zimbabwe to the risk of drought. They showed that socio-cognitive factors could more effectively explain adaptive behavior than purely socio-economic factors. Kroemker and Mossler (2002) suggest that two factors influence an individual's protection capacity: motivation and competence. When these two factors are high, only then will a person successfully carry out a 'protective' response. Another study by Wolf et al. (2010) examines the role of social capital in the adaptive capacity of elderly people to heat waves and finds that strong bonding and support networks are an important factor in decision making with respect to adaptation. The study found that these bonding networks may actually perpetuate a feeling of low-risk to heat waves among elderly societies and hence may in fact increase vulnerability, demonstrating the highly complex interplay of factors involved in supporting adaptive behavior.

In order to evaluate the validity of the notion that a locally focused information campaign strategy can more effectively motivate behavioral change, we designed a questionnaire aiming to test the effect of providing information focused on local impacts vs. global impacts on the perceived risk and adaptation motivation of private households from the city of Mannheim, Germany. We set up three hypotheses based on the predictions of theoretical considerations in the literature, which are elaborated below. 


\subsection{The link between perceived risk and motivation (Hypothesis 1)}

\section{Higher levels of perceived risk will lead to increased adaptive motivation.}

This hypothesis is largely based on the predictions made by Protection Motivation Theory (PMT), first presented by Rogers (1975) and later modified in different ways for application to different threat stimuli such as health threats (e.g. Rogers, 1983; Floyd et al., 2000). Recently, Grothmann and Reusswig (2006) further developed PMT, applying it to the issue of flood risks as well as to a German and European cultural context.

Recalling its definition by the IPCC, adaptation can in part be viewed as self-protective behavior of individuals or groups to reduce potentially harmful impacts of climate change. PMT, one of several psychological theories that have analyzed such kind of behavior and its underlying motivational processes, has generated some important insights with respect to protective, and hence, adaptive behavior. Consequently, we draw on concepts elaborated in the PMT model. However, unlike Grothmann and Reusswig, our study does not use the term protective responses, since it might be misleading in the context of this study. Instead, we aim to include all changes in behavior that allow one to adjust to a changing environment which are not necessarily all protective, and therefore use the terms adaptive responses and adaptation motivation in our analysis.

Going back to the earlier conceptions of PMT, Rogers (1983) proposed two independent appraisal processes that can be initiated by environmental as well as intrapersonal sources of information: threat appraisal and coping appraisal (Norman et al., 2005). Threat appraisal describes an individual's assessment of the severity of a potential threat stimulus if affected by it, as well as his or her personal vulnerability to the particular threat, i.e. the expectation of being affected by the threat. This means that if a person finds herself to be vulnerable to a perceived risk and assesses the threat as severe, her level of fear increases, leading to an increase in the motivation to protect herself.

Following the assessment of the threat under concern, a second cognitive process is subsequently initiated that is concerned with the possible reaction to the threat stimulus. This process is labeled coping appraisal and reflects the appraisal of potential coping behaviors in relation to one's own abilities and beliefs. According to Grothmann \& Reusswig (2006; p. 
105) this “(...) is what primarily differentiates PMT from the many studies of hazard perceptions and behavior in psychology (...)".Coping appraisal is also divided into different subcomponents. The appraisal, whether the behavior under concern can in fact serve as a protective measure against the anticipated threat, is called response efficacy and acts as the first component of coping appraisal within PMT (Norman et al., 2005). It is complemented by an assessment of one's own abilities to effectively carry out the adaptation behavior, which can be described as a person's perceived self-efficacy. Providing behavioral advice on certain adaptation measures, for example, may increase coping appraisal and therefore perceived adaptive capacity by raising the response efficacy of these measures (Grothmann and Patt, 2005). While these factors increase a person's motivation to engage in the protective behavior, the last factor of the coping appraisal can act to reduce the motivation as it is an analysis of the expected response costs that are incurred with the respective behavior.

Thus, if a threat causes a certain minimum level of concern in an individual's threat appraisal, he will analyze the available coping possibilities (coping appraisal), leading to a certain level of motivation to engage in the coping behavior (i.e. the protective behavior), labeled protection motivation.

According to PMT, protection motivation is increased by the factors severity, vulnerability, response efficacy and self efficacy, while the expected costs of protection will in turn reduce protection motivation. Therefore, in order to reach a sufficient level of protection motivation to elicit actual protection behavior, both threat and coping appraisal need to be sufficiently high. If threat appraisal is high, but coping appraisal is low, the response will be to engage in certain heuristics or what we call non-adaptive behaviors such as denial of the threat, wishful thinking (i.e. irrational belief that nothing will happen to oneself) or avoidance (i.e. not thinking about potential negative effects). Displacement of the responsibility of solving a problem is another example of a psychological barrier which might hinder autonomous adaptive action even in the case that a threat is recognized (World Development Report, 2010; StollKleemann et al., 2001; Whitmarsh, 2008). These responses result from psychological processes which act as barriers to actual behavioral change.

From the assumptions of PMT, we predict that there will be a positive impact of personal perceived risk (PPR), a term we use to label the outcome of the threat appraisal process, on the adaptation motivation. 


\subsection{Role of information on perceived risk (Hypothesis 2)}

Provision of information will increase the perceived severity and vulnerability of climate change threats, leading to higher levels of personal perceived risk compared to individuals receiving no information.

Several social and psychological barriers continue to act as obstacles to behavioral change with respect to adaptation. Studies have shown that one of these barriers is the large gap between the scientific community and general public in terms of understanding, awareness and perceptions of risk about climate change (Etkin and Ho, 2007; Kellstedt et al. 2008). A review of a compilation of 20 years of public opinion polls in the United States show that "few Americans are confident that they fully grasp the complexities of the issue, and on questions measuring actual knowledge about either the science or policy involved, the public scores are very low" (Nisbet and Myers, 2007, p. 447). This implies that although societies are aware and uneasy about climate change, they may not fully understand the fundamental science, possible effects, or the responses needed in order to ameliorate its impacts. According to Kroemker and Mossler (2002), knowledge about the specific causes and effects is vital for generating the motivation to engage in protective strategies, as well as increasing the range of adaptive strategies an individual is likely to choose from.

Furthermore, psychological research shows that individuals are ill-equipped to deal with multiple-cause problems because they can generally not be solved with one clear approach, often resulting in a sense of helplessness (Norgaard, 2006; World Development Report, 2010). The uncertain nature and onset of possible climate change effects, as well as constant media debates between skeptics and supporters, may lead to confusion and naturally deter any decisive, rational action. As a result, individuals tend to deny the threat or use heuristics such as unrealistic optimism which are likely to lead to under- or mis-estimations of threats in situations where uncertainty is high (Grothmann and Patt, 2005). Thus, the lack of understanding about the true causes and mechanisms of climate change may distort perceptions of risk among the public and hinder the implementation of any adaptive measures.

From an economic perspective, the uncertainty related to climate change and the imperfect information available to the public are evidently limiting factors when it comes to engaging in 
efficient adaptive actions. Information is required for private households and firms to make rational decisions and hence markets to operate in support of adaptation. It is widely stated throughout the literature that information is vital to ensure that adaptation is carried out in an adequate and timely manner (Stern, 2007; Dannenberg et al., in press; Mendelsohn, 2000; OECD, 2008). Thus, dissemination of research findings and predictions about future climate change impacts through information campaigns, including their temporal and spatial onset, is a key tool for increasing awareness of the general public.

As a result of these research findings, we predict that providing survey participants with information about climate change, irrespective of the focus of the information (local vs. global), will have a positive influence on personal perceived risk (PPR) compared to not supplying any information.

\subsection{The role of global vs. local information (Hypothesis 3)}

Locally focused information will increase personal perceived risk of individuals, compared to individuals receiving globally focused information.

Many current information campaigns focus on the unprecedented nature and scales of the problems related to climate change (World Development Report 2010). A study by Leiserowitz (2006) demonstrated that the majority of Americans perceived climate change as a moderate risk, and a danger to geographically and temporally distant people, places and nonhuman nature. The study found that most Americans lacked vivid, concrete, and personallyrelevant affective images of climate change, and consequently rated local impacts as somewhat unlikely. Moser and Dilling (2004) have also shown that Americans tend to discount the effects of climate change, perceiving the threats as occurring in the far future. This tends to be the case especially in developed countries. As a result, it has been a persistent challenge for scientists to stress the urgency for action against climate change to the general public (Nisbet and Myers, 2007).

This concurs with the criticisms of the well-known knowledge-deficit model, which was coined by social scientists in the 1980s and suggests that providing individuals with scientifically sound information will result in information assimilation, increased knowledge, action and support for policies based on this information (Adger, W.N. et al. 2007; Miller, 2001; 
Sturgis and Allum, 2004; Wright and Nerlich, 2006). However, surveys conducted in the UK and China examining the effects of information about long-term health conditions on behavior show that knowledge alone does not necessarily influence behavior. The research showed that understanding the context in which knowledge is used is vital to understanding its impacts on people's lives (Lorenzoni and Hulme, 2009). As has been shown, knowledge interacts with various psychological, cultural and economic factors at the community level that shape individuals' societal norms and personal value systems. As a result, not only an improvement in the awareness and understanding of climate change as a whole, but also of what will occur in a community's local surroundings and personal lives, will be necessary for prompting adequate adaptive responses.

Because vulnerability, coping ability, as well as the physical climate change impacts will vary greatly among different regions and communities, it is likely that using a more localized focus will be successful in increasing long-run resilience to climate change (Smit and Pilifosova, 2003). Wilbanks (2003) argues that in the context of sustainable development, stresses related to climate change are most usefully considered in a place-based perspective. In this manner, the scope of complex interrelationships involved in fostering social change can be examined more clearly and strategies for action, which may also offer co-benefits for sustainable development, can be more tangible and effective.

Klein et al. (1999) emphasize that the more detailed, accurate and relevant to the individual the climate change information is, the more effective the adaptation strategies undertaken will be. Moser and Dilling (2004) further state that in order to make global climate change relevant to the public, "global warming has to be made 'local' whether by directly focusing on impacts that matter to them, or indirectly by focusing on the co-benefits of climate friendly action" (Moser and Dilling, 2004, p. 500). Well-designed communication campaigns that address individuals as empowered members of a local community and not as helpless constituents of the global population as a whole can effectively promote action. In this manner, the problem becomes immediate and personally relevant and can stimulate local and individual responsibility for bringing about the solutions (World Development Report, 2010).

Evidence from community-based initiatives and activities indicates that individuals can feel enabled to responsibly modify their behavior through programs that (a) encourage individuals to take into account the impacts of their behavior on the environment and society; and (b) 
provide a supportive environment for individual and community decision-making (Adger et al., 2009). Thus, the design of effective adaptation interventions should reduce the transaction costs for individual decision making as well as enhance understanding about local risks, while taking into account community norms, values and beliefs.

In this study, PMT is used as a framework to test our hypotheses. By providing information with different spatial foci to our participants, we attempt to determine a potential effect on adaptation motivation. We postulate that providing locally focused information with respect to climate change will increase the personal perceived risk of individuals compared to individuals receiving globally focused information.

\section{Method}

157 participants from the general public of the German city of Mannheim took part in the survey. They responded to a randomly distributed invitation letter to take part in a "scientific study". Participants were invited by offering $30 €$ compensation for their participation in the study, which consisted of the completion of a questionnaire during one hour within the premises of the research institute. After registration via e-mail or telephone, participants were invited to one of 15 sessions overall with up to 15 participants at one time. The procedure was kept constant in all 15 sessions.

Participants received either the standard questionnaire without additional information input (control group), the local version including two pages of information about the local effects of climate change in South-West Germany (local group), or the global version including two pages of information about the global effects of climate change worldwide (global group). The information was extracted from the Summary for Policymakers of the fourth assessment report of the IPCC (2007c). The questionnaires for the different experimental conditions differed only in terms of the information supplied and were distributed randomly between the participants and the various session times. The control group consisted of 53 participants and both local and global experimental group of 52 participants each.

During the session, participants were asked to fill out Part 1 of the questionnaire and wait for the document to be collected. In this part of the questionnaire, respondents were asked to report several socio-demographic variables, including standard measures such as age, gender or 
education, as well as income levels, ownership of property, number of children, political preferences or their preferred mode of seeking or receiving information about climate change. Further, participants were asked about several objective measures of their level of knowledge about the predicted effects of climate change, their general interest and their overall attitudes with regard to the topic.

After collection of Part 1 of the questionnaire, participants were handed out Part 2. Here, the information stimulus (where applicable) was presented followed by a series of items to create a risk perception index score for each participant. Finally, the adaptation motivation was measured by testing the responses to four actual adaptation behaviors, namely (1) the understanding of the necessity to insure buildings against future climate change related damages, (2) the willingness to pay for higher energy standards in one's residence, (3) the understanding of the need to change one's personal lifestyle and habits due to an increasing climate change and (4) the acknowledgement that besides price, quality and brand the climatefriendliness of a product is an important factor for any purchasing decision.

Recalling the issue of the different definitions of adaptation, the current study draws on a broader conceptualization as its main concern is to shed light on the cognitive processes involved in behavioral change and their role in adjusting to changed climatic conditions. Defining adaptation as the protection against adverse climate damages or as taking advantage of the benefits of positive impacts, only measure (1) can be clearly defined as adaptation. Measures (2) and (3) can be understood as a mix of both mitigation and adaptation, whereas most would clearly think of mitigation when talking about measure (4). However, in the broader sense of adjusting the behavior to new external conditions, all four measures are adaptation measures and have hence been used to test adaptation motivation seen as a behavioral change. ${ }^{2}$

The specific items were constructed following a focus group discussion, and the questionnaire was pre-tested by around 30 people with academic and non-academic backgrounds and various ages. Most items were presented as statements and participants indicated their level of

\footnotetext{
${ }^{2}$ The need for a broad definition of adaptation for this survey is underlined by the answers to the open-end question "What do you think when you hear the term 'adaptation to climate change impacts'?". The results show that only $17.2 \%$ of the respondents name issues which are unambiguously adaptation measures in the sense of the IPCC definition. Half of the respondents (48.4\%) think at least partly of measures or issues clearly related to mitigation. The remaining participants responded mainly by naming some specific impact or did not respond at all.
} 
agreement using a uni-polar five-point Likert-Scale with a neutral mid-point. ${ }^{3}$ The personal perceived risk (PPR) was measured by an index constructed from a number of single items referring to the individual risk perception. In total, 17 items were aggregated by summing up their values. The assumptions behind this procedure are: a) each item is weighted equally, and b) equidistance of the Likert-scale-values. ${ }^{4}$ A sensitivity analysis with regard to the second assumption, i.e. the use of a dummy-based index ${ }^{5}$, shows no differing results. Descriptive statistics for all variables used in the analysis are presented in Table 1.

\footnotetext{
${ }^{3}$ A uni-polar Likert-scale describes a scale with numerical values extending in one direction, in the case of a five-point scale from one to five. The values are given verbal labels ("strongly do not agree", "rather do not agree", "neutral", "rather agree", "strongly agree").

4 The validity of interval-based procedures in connection with Likert-scale data is raised by Jaccard and Wan (1996). The authors review several contributions to this topic, summarizing that for many statistical tests the errors caused by non-ordinal procedures are not dramatic. Also Chan (1996) found that the strong assumption of equidistance is "not very harmful". However, all cited sources stress the necessity of at least 5 points on the Likert-scale. This precondition is fulfilled in our study.

${ }^{5}$ The dummy-based PPR index is constructed as follows: Each answer of an individual to a PPR item is counted as 1, if the individual shows a high or very high PPR ("rather agree" or "strongly agree"). As there are 17 PPRitems, the theoretical range of the dummy-based index is 0 to 17 , with larger values indicating a higher PPR.
} 
Table 1: Descriptive statistics of used variables. $-{ }^{\mathrm{a}}$ ) Non-integer values result from missing values in some $(2.4 \%)$ of the answers to the 17 sub-items, which are replaced by the respondent's average response to PPR items. $\left.-{ }^{\mathrm{b}}\right)$ Dummy-variables.

\begin{tabular}{|c|c|c|c|c|}
\hline Variable & Mean & $\begin{array}{l}\text { Standard } \\
\text { deviation }\end{array}$ & Minimum & Maximum \\
\hline $\begin{array}{l}\text { Motivation for adaptation measure (1): Acknowledging the increasing relev- } \\
\text { ance of a building insurance }\end{array}$ & 2.2566 & 1.1480 & 1 & 5 \\
\hline $\begin{array}{l}\text { Motivation for adaptation measure (2): willingness to pay for higher energy } \\
\text { standards in the residence }\end{array}$ & 3.7857 & 1.1770 & 1 & 5 \\
\hline $\begin{array}{l}\text { Motivation for adaptation measure (3): acknowledging the necessity to change } \\
\text { habits and life style in the future due to climate change }\end{array}$ & 3.3013 & 1.1608 & 1 & 5 \\
\hline $\begin{array}{l}\text { Motivation for adaptation measure (4): beside price and quality, climate- } \\
\text { friendly features of goods and services are relevant for purchasing decisions }\end{array}$ & 3.3935 & 1.1537 & 1 & 5 \\
\hline PPR (as Summated score of PPR items) ${ }^{a}$ & 59.4474 & 11.3702 & 26 & 82.7333 \\
\hline $\begin{array}{l}\text { PPR (as Summated score of PPR items, standardized to a value between } 0 \text { and } \\
\text { 1) }\end{array}$ & 0.6242 & 0.1672 & 0.1326 & 0.9667 \\
\hline PPR (dummy-based, as number of PPR items with high or very high score) & 8.6943 & 3.4188 & 1 & 16 \\
\hline Information $^{b}$ & 0.6624 & 0.4744 & 0 & 1 \\
\hline Local information $^{b}$ & 0.3312 & 0.4722 & 0 & 1 \\
\hline Gender: female ${ }^{b}$ & 0.5414 & 0.4999 & 0 & 1 \\
\hline Age & 40.2774 & 17.0837 & 19 & 85 \\
\hline Children $^{\text {b }}$ & 0.3526 & 0.4793 & 0 & 1 \\
\hline High Education $^{\mathrm{b}}$ & 0.6968 & 0.4611 & 0 & 1 \\
\hline High Income $^{b}$ & 0.4295 & 0.4967 & 0 & 1 \\
\hline Home-owner $^{b}$ & 0.3376 & 0.4744 & 0 & 1 \\
\hline Agreement to statement "Climate change is biggest challenge for mankind" b & 0.2803 & 0.4506 & 0 & 1 \\
\hline Interest for climate change ${ }^{b}$ & 0.8397 & 0.3680 & 0 & 1 \\
\hline Revealed knowledge on climate change & 0.7898 & 0.8009 & 0 & 3 \\
\hline Feeling influenced by mass media ${ }^{b}$ & 0.5833 & 0.4946 & 0 & 1 \\
\hline Stated experience of climate change impacts ${ }^{b}$ & 0.2803 & 0.4506 & 0 & 1 \\
\hline Stated Expectation of Public Relief in case of need ${ }^{b}$ & 0.1274 & 0.3345 & 0 & 1 \\
\hline
\end{tabular}

\section{Results and Discussion}

As the adaptation motivation was measured by a 5-point Likert-scale, the dependent variable is ordered and categorical. We therefore estimate the influence of the determining factors on the different adaptation measures by an ordered-logit model, with various possible influencing variables such as socio-demographics, attitudes towards climate change, revealed knowledge on climate change, the stated expectation of state relief and finally the PPR index. The results of the econometric analysis are presented in Table 2. 
Table 2: Results of multivariate regressions to test hypothesis (1): "Higher levels of perceived risk will lead to increased protective motivation".

\begin{tabular}{|c|c|c|c|c|}
\hline $\begin{array}{l}\text { Ordered Logit } \\
\text { (standard deviations in parenthesis) }\end{array}$ & $\begin{array}{l}\text { Adaptation } \\
\text { measure (1) }\end{array}$ & $\begin{array}{l}\text { Adaptation } \\
\text { measure (2) }\end{array}$ & $\begin{array}{l}\text { Adaptation } \\
\text { measure (3) }\end{array}$ & $\begin{array}{l}\text { Adaptation } \\
\text { measure (4) }\end{array}$ \\
\hline $\begin{array}{l}\text { Double-sided test: } \\
* * *=\text { significant at the } 1 \% \text {-level } \\
* *=\text { significant at the } 5 \% \text {-level } \\
*=\text { significant at the } 10 \% \text {-level }\end{array}$ & $\begin{array}{l}\text { Understanding of the } \\
\text { necessity to insure } \\
\text { buildings against future } \\
\text { climate change related } \\
\text { damages } \\
\mathrm{N}=138\end{array}$ & $\begin{array}{l}\text { Willingness to pay for } \\
\text { higher energy stan- } \\
\text { dards in one's resi- } \\
\text { dence } \\
\mathrm{N}=140\end{array}$ & $\begin{array}{l}\text { Understanding of the } \\
\text { need to change one's } \\
\text { personal lifestyle and } \\
\text { habits due to an in- } \\
\text { creasing climate } \\
\text { change } \\
\mathrm{N}=142\end{array}$ & $\begin{array}{l}\text { Acknowledgement that } \\
\text { besides price, quality } \\
\text { and brand the climate- } \\
\text { friendliness of a prod- } \\
\text { uct is an important } \\
\text { factor for any purchas- } \\
\text { ing decision } \\
\mathrm{N}=141\end{array}$ \\
\hline Personal Perceived Risk & $\begin{array}{c}0.0528 * * * \\
(0.0189)\end{array}$ & $\begin{array}{l}0.0490 * * \\
(0.0197)\end{array}$ & $\begin{array}{c}0.1234 * * * \\
(0.0258)\end{array}$ & $\begin{array}{c}0.0579 * * * \\
(0.0184)\end{array}$ \\
\hline Interaction PPR Gender: female & - & - & $\begin{array}{c}-0.0945 * * * \\
(0.0361)\end{array}$ & - \\
\hline Gender: female & $\begin{array}{l}0.3764 \\
(0.3526)\end{array}$ & $\begin{array}{c}-0.8104 * * \\
(0.3526)\end{array}$ & $\begin{array}{c}7.0566 * * * \\
(2.2732)\end{array}$ & $\begin{array}{l}-0.0258 \\
(0.3440)\end{array}$ \\
\hline Age & $\begin{array}{l}-0.0017 \\
(0.0137)\end{array}$ & $\begin{array}{l}0.0083 \\
(0.0134)\end{array}$ & $\begin{array}{l}-0.0136 \\
(0.0139)\end{array}$ & $\begin{array}{c}0.0532 * * * \\
(0.0150)\end{array}$ \\
\hline Children & $\begin{array}{l}-0.3880 \\
(0.4431)\end{array}$ & $\begin{array}{l}0.1217 \\
(0.4371)\end{array}$ & $\begin{array}{l}0.6574 \\
(0.4430)\end{array}$ & $\begin{array}{l}0.5722 \\
(0.4387)\end{array}$ \\
\hline Education & $\begin{array}{c}-0.8521 * * \\
(0.4021)\end{array}$ & $\begin{array}{l}0.9479 * * \\
(0.3986)\end{array}$ & $\begin{array}{l}-0.5568 \\
(0.3999)\end{array}$ & $\begin{array}{l}0.5585 \\
(0.4101)\end{array}$ \\
\hline Income & $\begin{array}{l}0.3263 \\
(0.3595)\end{array}$ & $\begin{array}{l}-0.4473 \\
(0.3672)\end{array}$ & $\begin{array}{l}2.5776 * * * \\
(0.5934)\end{array}$ & $\begin{array}{l}0.4200 \\
(0.3657)\end{array}$ \\
\hline Interaction Income $*$ Gender & - & - & $\begin{array}{c}-1.5092 * * \\
(0.7316)\end{array}$ & - \\
\hline Home-owner & $\begin{array}{l}0.3082 \\
(0.3759)\end{array}$ & $\begin{array}{c}-0.7508 * \\
(0.3889)\end{array}$ & $\begin{array}{l}-0.7157 * \\
(0.3897)\end{array}$ & $\begin{array}{l}-0.2785 \\
(0.3777)\end{array}$ \\
\hline $\begin{array}{l}\text { Agreement to statement "Climate } \\
\text { change is biggest challenge for } \\
\text { mankind" }\end{array}$ & $\begin{array}{l}-0.1265 \\
(0.3848)\end{array}$ & $\begin{array}{l}0.7662 * \\
(0.3917)\end{array}$ & $\begin{array}{l}0.5102 \\
(0.3949)\end{array}$ & $\begin{array}{l}-0.4222 \\
(0.3802)\end{array}$ \\
\hline Interest for climate change & $\begin{array}{l}-0.5084 \\
(0.4481)\end{array}$ & $\begin{array}{l}-0.0008 \\
(0.4140)\end{array}$ & $\begin{array}{l}0.9059 * \\
(0.4738)\end{array}$ & $\begin{array}{c}1.1679 * * * \\
(0.4303)\end{array}$ \\
\hline $\begin{array}{l}\text { Revealed knowledge on climate } \\
\text { change }\end{array}$ & $\begin{array}{c}-0.5038 * * \\
(0.2329)\end{array}$ & $\begin{array}{l}0.2301 \\
(0.2260)\end{array}$ & $\begin{array}{l}0.2503 \\
(0.2310)\end{array}$ & $\begin{array}{l}0.2209 \\
(0.2196)\end{array}$ \\
\hline Feeling influenced by mass media & $\begin{array}{l}0.1074 \\
(0.3522)\end{array}$ & $\begin{array}{l}-0.0784 \\
(0.3492)\end{array}$ & $\begin{array}{c}0.3967 \\
(0.3552)\end{array}$ & $\begin{array}{l}0.0935 \\
(0.3478)\end{array}$ \\
\hline $\begin{array}{l}\text { Stated experience of climate } \\
\text { change impacts }\end{array}$ & $\begin{array}{l}0.0849 \\
(0.3820)\end{array}$ & $\begin{array}{l}-0.1055 \\
(0.3688)\end{array}$ & $\begin{array}{l}0.5842 \\
(0.3944)\end{array}$ & $\begin{array}{l}0.6104 \\
(0.3863)\end{array}$ \\
\hline $\begin{array}{l}\text { Stated Expectation of Public } \\
\text { Relief in case of need }\end{array}$ & $\begin{array}{l}0.2726 \\
(0.4815)\end{array}$ & $\begin{array}{l}0.9910 * * \\
(0.5008)\end{array}$ & $\begin{array}{l}0.4662 \\
(0.4847)\end{array}$ & $\begin{array}{l}-0.2172 \\
(0.4726)\end{array}$ \\
\hline Pseudo-R ${ }^{2}$ & 0.0791 & 0.0705 & 0.1681 & 0.1453 \\
\hline
\end{tabular}

We want to highlight the expected positive influence of PPR on adaptation motivation which is significant at the $1 \%$-level over three of four analyzed measures - for measure (2) it is significant at the $5 \%$-level. These results support hypothesis (1) that higher PPR leads to a high- 
er motivation to adapt. ${ }^{6}$ Besides the reported coefficients, Figure 1 illustrates the positive influence of PPR on the motivation to adapt. The graphs show the predicted probabilities of answering in the respective category for each level of PPR, based upon the fitted orderedlogit model. Note that by tendency the probabilities of "high motivation" answers are increasing with rising PPR levels and vice versa.

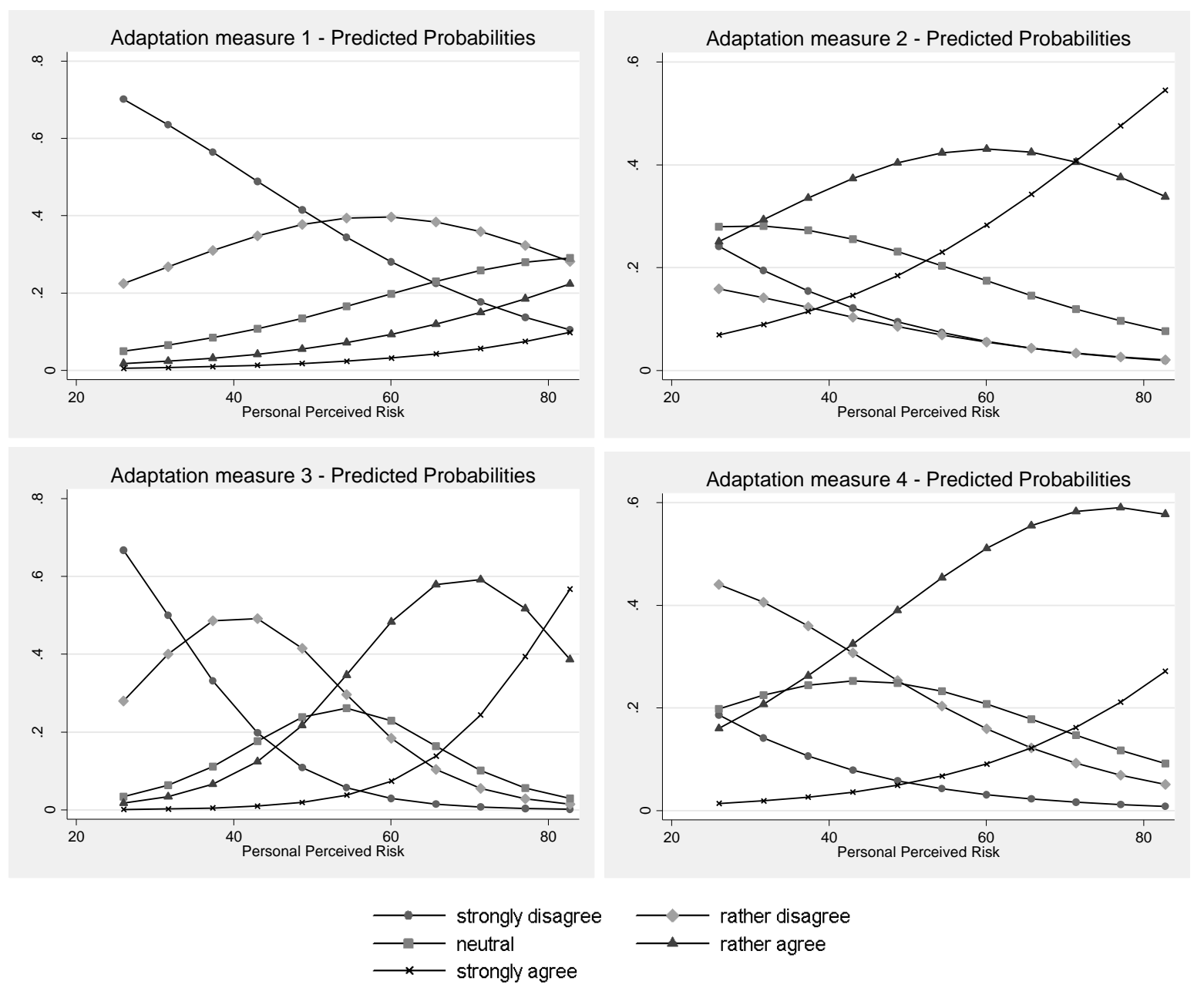

Figure 1: Predicted probabilities of answer categories for the four different adaptation measures and the Personal Perceived Risk. The four adaptation options are

(1) the understanding of the necessity to insure buildings against future climate change related damages,

(2) the willingness to pay for higher energy standards in one's residence,

(3) the understanding of the need to change one's personal lifestyle and habits due to an increasing climate change and

(4) the acknowledgement that besides price, quality and brand the climate-friendliness of a product is an important factor for any purchasing decision.

However, we also acknowledge the relatively low share of explained variance in our regressions. One important reason may be that coping appraisal, which apart from threat appraisal is also a main determinant of motivation to adapt according to PMT, was unobserved in the current study. Due to the presented findings and the relative importance of coping appraisal with-

\footnotetext{
${ }^{6}$ It is worth mentioning that this effect in some cases is lower for females than for males, indicating at least in the case of measure (3) that females generally have a higher motivation to adapt, resulting in a lower incremental
} 
in the theoretical framework of PMT, further research may be focused more upon the role of increasing specific knowledge about coping options. In particular, as the respondents were not given concrete behavioral advice on specific adaptation measures that they could potentially undertake, a separate look into the effects of providing such kind of behavioral advice might be worthwhile in the light of the current results. This specific knowledge is likely to be a determinant in successfully motivating individuals to adapt (e.g. Fankhauser and Tol, 1997), but was not included in this analysis due to its focus on the effect of providing different types of information on people's perceived risk.

Other important variables may be social norms which act as a barrier to behavioral change. Social norms may influence the motivation to adapt, as they produce and guide action in direct and meaningful ways, especially under conditions of uncertainty (Norgaard, 2006; Schultz et al., 2007; World Development Report, 2010). Hence, social capital, or the sets of norms and networks that an individual uses to mediate the flow of information with other individuals, is a vital element in the management of adaptation to environmental change (Adger, 2003).

The results show that PPR indeed has an influence on the motivation to adapt, but explains only a small share of observed variance, suggesting that a high threat appraisal is a necessary but not sufficient precondition to increase motivation to adapt.

In order to analyze hypothesis (2) (the influence of information on PPR), first a Wilcoxon rank sum test was applied to test for a significant difference in PPR by different treatment groups. Although the PPR is higher for informed individuals than for others, the difference is not significant at the $10 \%$ level. Thus, the test does not suggest a difference in the distribution of PPR regarding the information treatment (see Table 3).

increase when PPR increases. 
Table 3: Wilcoxon rank sum test for equality of distributions of PPR in different information treatments. H0: Distributions of PPR in both groups are equal - H1: Distributions of PPR in both groups differ from each other. *) For using the PPR as summated score of PPR items see footnote 4.

\begin{tabular}{|c|c|c|c|c|c|}
\hline Variable & $\begin{array}{l}\text { Information } \\
\text { group }\end{array}$ & $\mathbf{N}$ & Mean* & $\begin{array}{l}\text { Wilcoxon } \\
\text { rank sum }\end{array}$ & $\begin{array}{l}\text { p-value (rejec- } \\
\text { tion of } H 1 \text { ) }\end{array}$ \\
\hline \multirow{2}{*}{$\begin{array}{l}\text { PPR (as sum- } \\
\text { mated score of } \\
\text { PPR items)* }\end{array}$} & $\begin{array}{l}\text { Provision of } \\
\text { information }\end{array}$ & 104 & 60.11 & 8439.5 & \multirow{2}{*}{0.4066} \\
\hline & $\begin{array}{l}\text { No provision of } \\
\text { information }\end{array}$ & 53 & 58.14 & 3963.5 & \\
\hline \multirow{2}{*}{$\begin{array}{l}\text { PPR (as number } \\
\text { of PPR items } \\
\text { with high or very } \\
\text { high PPR) }\end{array}$} & $\begin{array}{l}\text { Provision of } \\
\text { information }\end{array}$ & 104 & 8.9231 & 8516.5 & \multirow{2}{*}{0.2622} \\
\hline & $\begin{array}{l}\text { No provision of } \\
\text { information }\end{array}$ & 53 & 8.2453 & 3886.5 & \\
\hline
\end{tabular}

Second, the PPR index is taken as the dependent variable in a socio-psychological model to find the marginal influence of information, controlling for socio-economic and psychological variables and for general attitudes towards climate change. To take account of the limited range of the dependent variable, we transform the sum of PPR-items to a variable which takes values between 0 and 1 and use a fractional logit model (Papke and Wooldridge 1996). The common OLS model is used as a reference. Furthermore, the mentioned OLS estimation of the dummy-based PPR-index as a sensitivity analysis with regard to the equidistanceassumption of the Likert-scale is presented. Contrary to the expectation and consistent with the results of the Wilcoxon rank sum test, the results in Table 4 show no significant influence of information on the PPR index compared to no information, regardless of which aggregation method for the PPR index or econometric method is used. Thus, the alternative hypothesis that the provision of information on climate change impacts has no effect on the PPR cannot be rejected at the $10 \%$ level; this means hypothesis (2) is not supported by the data. However, we find significant positive effects of the variables Gender, Experience of climate impacts, perceived influence of mass media, along with significant negative effects of Revealed Knowledge on climate change. 
Table 4: Results of multivariate regressions to test hypothesis (2): "Provision of information will increase the perceived severity and vulnerability of climate change threats, leading to higher levels of personal perceived risk compared to individuals receiving no information".

\begin{tabular}{|c|c|c|c|}
\hline $\begin{array}{l}\mathbf{N}=\mathbf{1 4 2} \\
\text { (standard deviations in parenthesis) } \\
\text { Double-sided test: } \\
* * *=\text { significant at the } 1 \% \text {-level } \\
* *=\text { significant at the } 5 \% \text {-level } \\
*=\text { significant at the } 10 \% \text {-level }\end{array}$ & $\begin{array}{l}\text { Fractional Logit } \\
\text { Dependent variable: } \\
\text { Summated score of PPR } \\
\text { items, standardized to a } \\
\text { value between } 0 \text { and } 1\end{array}$ & $\begin{array}{l}\text { OLS } \\
\text { Dependent Variable: } \\
\text { Summated score of PPR } \\
\text { items }\end{array}$ & $\begin{array}{l}\text { OLS } \\
\text { Dependent variable: } \\
\text { Number of PPR items with } \\
\text { high or very high PPR }\end{array}$ \\
\hline Information & $\begin{array}{l}0.0234 \\
(0.1124)\end{array}$ & $\begin{array}{c}0.4690 \\
(1.7176)\end{array}$ & $\begin{array}{l}0.4380 \\
(0.5429)\end{array}$ \\
\hline Gender: female & $\begin{array}{l}0.2777 * * \\
(0.1089)\end{array}$ & $\begin{array}{l}4.3450 * * \\
(1.6820)\end{array}$ & $\begin{array}{l}1.3517 * * \\
(0.5316)\end{array}$ \\
\hline Age & $\begin{array}{l}0.0008 \\
(0.0040)\end{array}$ & $\begin{array}{l}0.0130 \\
(0.0681)\end{array}$ & $\begin{array}{l}0.0086 \\
(0.0215)\end{array}$ \\
\hline Children & $\begin{array}{l}0.0478 \\
(0.1291)\end{array}$ & $\begin{array}{l}0.7830 \\
(2.1752)\end{array}$ & $\begin{array}{l}0.1037 \\
(0.6875)\end{array}$ \\
\hline Education & $\begin{array}{l}-0.1769 \\
(0.1171)\end{array}$ & $\begin{array}{l}-2.5783 \\
(1.9642)\end{array}$ & $\begin{array}{l}-0.8177 \\
(0.6208)\end{array}$ \\
\hline Income & $\begin{array}{l}-0.0807 \\
(0.1157)\end{array}$ & $\begin{array}{l}-1.2711 \\
(1.8155)\end{array}$ & $\begin{array}{l}-0.2050 \\
(0.5738)\end{array}$ \\
\hline Home-owner & $\begin{array}{l}0.1956^{*} \\
(0.1170)\end{array}$ & $\begin{array}{l}2.9743 \\
(1.8786)\end{array}$ & $\begin{array}{c}0.6344 \\
(0.5938)\end{array}$ \\
\hline $\begin{array}{l}\text { Agreement to statement "Climate } \\
\text { change is biggest challenge for } \\
\text { mankind" }\end{array}$ & $\begin{array}{l}0.2509 * * \\
(0.1129)\end{array}$ & $\begin{array}{l}3.6276^{*} \\
(1.8875)\end{array}$ & $\begin{array}{l}0.7344 \\
(0.5966)\end{array}$ \\
\hline Interest for climate change & $\begin{array}{l}-0.0180 \\
(0.1349)\end{array}$ & $\begin{array}{l}-0.2291 \\
(2.2430)\end{array}$ & $\begin{array}{l}0.2816 \\
(0.7089)\end{array}$ \\
\hline $\begin{array}{l}\text { Revealed knowledge on climate } \\
\text { change }\end{array}$ & $\begin{array}{c}-0.2200 * * * \\
(0.0645)\end{array}$ & $\begin{array}{c}-3.4723 \text { *** } \\
(1.0865)\end{array}$ & $\begin{array}{c}-0.8366^{* *} \\
(0.3434)\end{array}$ \\
\hline Feeling influenced by mass media & $\begin{array}{c}0.3486 * * * \\
(0.1026)\end{array}$ & $\begin{array}{c}5.3418 * * * \\
(1.6937)\end{array}$ & $\begin{array}{c}1.5826 * * * \\
(0.5353)\end{array}$ \\
\hline $\begin{array}{l}\text { Experience of climate change im- } \\
\text { pacts }\end{array}$ & $\begin{array}{c}0.3036 * * * \\
(0.1117)\end{array}$ & $\begin{array}{c}4.5999 \text { *** } \\
(1.8280)\end{array}$ & $\begin{array}{c}1.4098 * * \\
(0.5778)\end{array}$ \\
\hline Constant & $\begin{array}{c}0.2498 \\
(0.2668)\end{array}$ & $\begin{array}{c}55.1049 * * * \\
(3.7570)\end{array}$ & $\begin{array}{c}6.7807 * * * \\
(1.1875)\end{array}$ \\
\hline Goodness of fit: R2 & 0.3119 & 0.3108 & 0.2601 \\
\hline
\end{tabular}

One important reason why the presentation of expected climate change impacts does not increase the personal risk appraisal might be the relatively low severity of presented climate impacts in the study region. Many of the participants in the study expected much more severe climate impacts, demonstrated by their answers on open-end knowledge questions such as current sea level and temperature increase estimates for a decade. This may in part be influenced by the frequent exposure to dramatic images and extensive coverage of devastating 
events in the media, as reflected by the highly significant, positive impact of the variable "Feeling influenced by mass media". Since the information on the impacts of climate change did not surpass their expectations, as illustrated by the data in Table 5, their PPR may not have increased. ${ }^{7}$

Table 5: Results of knowledge questions.

\begin{tabular}{|c|c|c|c|c|}
\hline & $\begin{array}{l}\text { Underestimation of im- } \\
\text { pacts including state- } \\
\text { ments of "no impact" } \\
\text { and decrease }\end{array}$ & $\begin{array}{l}\text { Value given by } \\
\text { climate science } \\
\text { (IPCC 2007a) }\end{array}$ & $\begin{array}{l}\text { Overestimation } \\
\text { of impacts }\end{array}$ & $\begin{array}{l}\text { Don't } \\
\text { know- } \\
\text { answers }\end{array}$ \\
\hline $\begin{array}{l}\text { Sea level rise } \\
\text { in } 10 \text { years }\end{array}$ & $\begin{array}{l}\text { decrease, no change and } \\
\text { increase up to } 13 \mathrm{~mm}\end{array}$ & $\begin{array}{l}\text { increase between } \\
13 \mathrm{~mm} \text { and } 38 \mathrm{~mm}\end{array}$ & $\begin{array}{l}\text { increase by more } \\
\text { than } 38 \mathrm{~mm}\end{array}$ & \\
\hline $\begin{array}{l}\text { Share of res- } \\
\text { ponses }(\%)\end{array}$ & 12.9 & 18.1 & 46.4 & 22.6 \\
\hline $\begin{array}{l}\text { Global tem- } \\
\text { perature } \\
\text { change in } 10 \\
\text { years }\end{array}$ & $\begin{array}{l}\text { decrease, no change and } \\
\text { increase up to } 0.04^{\circ} \mathrm{C}\end{array}$ & $\begin{array}{l}\text { increase between } \\
0.04^{\circ} \mathrm{C} \text { and } 0.16^{\circ} \mathrm{C}\end{array}$ & $\begin{array}{l}\text { increase by more } \\
\text { than } 0.16^{\circ} \mathrm{C}\end{array}$ & \\
\hline $\begin{array}{l}\text { Share of res- } \\
\text { ponses }(\%)\end{array}$ & 5.8 & 1.9 & 82.6 & 9.7 \\
\hline
\end{tabular}

Moreover, psychological barriers such as denial and other heuristics discussed earlier in this paper, may have led to a negation of the risks and thus a PPR not changed by information on these risks.

The stated experience of climate change impacts has a highly significant, positive effect on the PPR index in our sample. Given the relatively low exposure to climate change of the locality, this variable deserves a closer look. $28 \%$ of the respondents $(\mathrm{N}=44)$ state that they have experienced some impact of climate change. Being asked about the felt severity of their experience, $43 \%(\mathrm{~N}=19)$ respond it was "severe" or "very severe". Respondents are also asked to name the most relevant impacts for their personal life. In the group of severe impacts the impact category "high temperatures in summer" (or equivalent answers like "heat waves") is highly predominant. These details should help in evaluating what is understood as "experience" by the respondents in our sample.

For comparing the effect of locally versus globally focused information, the same procedures (Wilcoxon rank sum test for comparing means and multivariate econometric estimation with a dummy for local information as an independent variable) are used. Again, the data does not

\footnotetext{
${ }^{7}$ The comparably low severity of climate change impacts in the study region is also reflected by the influence of "Revealed knowledge" on PPR. Those respondents who have some objective knowledge about the impacts reveal a significantly lower PPR than those who rank lower in the knowledge scale.
} 
suggest a significant difference in the impact of information depending on its focus, although PPR is slightly higher for locally-informed individuals (see Table 6 and Table 7). Consequently, the alternative hypothesis to hypothesis (3) cannot be rejected, either.

Table 6: Wilcoxon rank sum test for equality of distributions of PPR in different information treatments. H0: Distributions of PPR in both groups are equal - H1: Distributions of PPR in both groups differ from each other. *) For using the PPR as summated score of PPR items see footnote 4.

\begin{tabular}{|l|l|l|l|c|c|}
\hline Variable & $\begin{array}{l}\text { Information } \\
\text { group }\end{array}$ & $\mathbf{N}$ & Mean & $\begin{array}{l}\text { Wilcoxon } \\
\text { rank sum }\end{array}$ & $\begin{array}{c}\text { p-value (rejec- } \\
\text { tion of H1) }\end{array}$ \\
\hline \multirow{2}{*}{$\begin{array}{l}\text { PPR (as sum- } \\
\text { mated score of } \\
\text { PPR items)* }\end{array}$} & $\begin{array}{l}\text { Globally focussed } \\
\text { information }\end{array}$ & 52 & 59.22 & 2570.5 & \multirow{2}{*}{0.2996} \\
\cline { 2 - 5 } & $\begin{array}{l}\text { Locally focussed } \\
\text { information }\end{array}$ & 52 & 61.01 & 2889.5 & \multirow{2}{*}{0.5319} \\
\hline $\begin{array}{l}\text { PPR (as Number } \\
\text { of PPR items } \\
\text { with high or very } \\
\text { high PPR) }\end{array}$ & $\begin{array}{l}\text { Globally focussed } \\
\text { information }\end{array}$ & 52 & 8.7885 & 2634.5 & \\
\cline { 2 - 5 } & $\begin{array}{l}\text { Locally focussed } \\
\text { information }\end{array}$ & 52 & 9.0577 & 2825.5 & \\
\hline
\end{tabular}


Table 7: Results of multivariate regressions to test hypothesis (3): "Locally focused information will increase the severity and vulnerability of threat appraisal, compared to individuals receiving globally focused information."

\begin{tabular}{|c|c|c|c|}
\hline $\begin{array}{l}\text { Only informed individu- } \\
\text { als, } \mathbf{N}=\mathbf{9 3} \\
\text { (standard deviations in parenthesis) } \\
\text { Double-sided test: } \\
* * *=\text { significant at the } 1 \% \text {-level } \\
* *=\text { significant at the } 5 \% \text {-level } \\
*=\text { significant at the } 10 \% \text {-level }\end{array}$ & $\begin{array}{l}\text { Fractional Logit } \\
\text { Dependent variable: } \\
\text { Summated score of PPR } \\
\text { items, standardized to a } \\
\text { value between } 0 \text { and } 1\end{array}$ & $\begin{array}{l}\text { OLS } \\
\text { Dependent Variable: } \\
\text { Summated score of PPR } \\
\text { items }\end{array}$ & $\begin{array}{l}\text { OLS } \\
\text { Dependent variable: } \\
\text { Number of PPR items with } \\
\text { high or very high PPR }\end{array}$ \\
\hline Locally-focused information & $\begin{array}{l}0.0197 \\
(0.1271)\end{array}$ & $\begin{array}{l}0.3206 \\
(2.0526)\end{array}$ & $\begin{array}{l}0.2599 \\
(0.6489)\end{array}$ \\
\hline Gender: female & $\begin{array}{l}0.2039 \\
(0.1262)\end{array}$ & $\begin{array}{l}3.1524 \\
(2.0224)\end{array}$ & $\begin{array}{l}0.9028 \\
(0.6394)\end{array}$ \\
\hline Age & $\begin{array}{l}0.0014 \\
(0.0049)\end{array}$ & $\begin{array}{l}0.0143 \\
(0.0902)\end{array}$ & $\begin{array}{l}0.0092 \\
(0.0285)\end{array}$ \\
\hline Children & $\begin{array}{l}0.1422 \\
(0.1451)\end{array}$ & $\begin{array}{l}2.4090 \\
(2.8152)\end{array}$ & $\begin{array}{c}1.0101 \\
(0.8900)\end{array}$ \\
\hline Education & $\begin{array}{l}-0.2935 * \\
(0.1609)\end{array}$ & $\begin{array}{l}-4.2578 \\
(2.5868)\end{array}$ & $\begin{array}{l}-1.0493 \\
(0.8178)\end{array}$ \\
\hline Income & $\begin{array}{l}-0.1965 \\
(0.1269)\end{array}$ & $\begin{array}{l}-2.9265 \\
(2.1691)\end{array}$ & $\begin{array}{l}-0.7324 \\
(0.6858)\end{array}$ \\
\hline Home-owner & $\begin{array}{l}0.2718 * \\
(0.1470)\end{array}$ & $\begin{array}{l}3.9894 * \\
(2.2816)\end{array}$ & $\begin{array}{l}0.7541 \\
(0.7213)\end{array}$ \\
\hline $\begin{array}{l}\text { Agreement to statement "Climate } \\
\text { change is biggest challenge for man- } \\
\text { kind" }\end{array}$ & $\begin{array}{l}0.2300 * \\
(0.1356)\end{array}$ & $\begin{array}{l}3.2459 \\
(2.2670)\end{array}$ & $\begin{array}{c}0.5902 \\
(0.71767)\end{array}$ \\
\hline Interest for climate change & $\begin{array}{l}0.0514 \\
(0.1751)\end{array}$ & $\begin{array}{l}0.8928 \\
(2.7561)\end{array}$ & $\begin{array}{l}0.8826 \\
(0.8714)\end{array}$ \\
\hline Revealed knowledge on climate change & $\begin{array}{c}-0.2568 * * * \\
(0.0759)\end{array}$ & $\begin{array}{c}-3.9957 * * * \\
(1.2743)\end{array}$ & $\begin{array}{c}-0.8783 * * \\
(0.4029)\end{array}$ \\
\hline Feeling influenced by mass media & $\begin{array}{c}0.3777 * * * \\
(0.1292)\end{array}$ & $\begin{array}{c}5.7397 * * * \\
(2.1442)\end{array}$ & $\begin{array}{c}1.5295 * * \\
(0.6779)\end{array}$ \\
\hline Experience of climate change impacts & $\begin{array}{c}0.4047 \text { *** } \\
(0.1242)\end{array}$ & $\begin{array}{c}6.0809 * * * \\
(2.1607)\end{array}$ & $\begin{array}{c}1.7348 * * \\
(0.6831)\end{array}$ \\
\hline Constant & $\begin{array}{c}0.2961 \\
(0.3839)\end{array}$ & $\begin{array}{c}55.9701 \text { *** } \\
(4.8786)\end{array}$ & $\begin{array}{c}6.8821 * * * \\
(1.5424)\end{array}$ \\
\hline Goodness of fit: $\mathrm{R2}$ & 0.3683 & 0.3665 & 0.2757 \\
\hline
\end{tabular}

Here we see a potential tradeoff between spatial-temporal distance and the severity of the information presented. Although the literature suggests that focusing on more personally relevant effects which may occur in one's surroundings is more likely to increase threat appraisal and ultimately to inspire adaptive behavior, the severity of the information is also crucial. Since the predicted climate effects in Germany are relatively mild, and even beneficial in 
some cases, participants may not have experienced an increase in perceived risk. A further factor that might explain the finding of non-significant effects for hypothesis 2 and 3 might be the relatively small sample size. As most effects can be observed in the predicted direction, however not at a significance level of $10 \%$, the use of a larger sample might allow for a better identification of the investigated effects and should be applied in future studies.

\section{Economic classification of the results}

In the preceding sections we analyzed changes in behavior in response to climate change, regardless of their classification according to the IPCC as adaptation or mitigation. In contrast to the rest of this paper, in this paragraph adaptation as distinct from mitigation is defined as in IPCC (2007b), as the reduction of climate damages and the exploitation of potential benefits from climate change. This distinction is important since from an economic viewpoint mitigation of climate change is substantially different from adaptation (Dannenberg et al. in press; Tol, 2005). The most important difference with severe consequences is the incentive structure for private agents. From an economic viewpoint, autonomous adaptation is characterized by private, utility-maximizing calculus. ${ }^{8}$ It can be seen as economically rational behavior in the view or expectation of environmental changes, under consideration of the time horizon (which means the avoidance of future losses and the exploitation of future benefits are discounted to net present values) and the uncertainty of climate effects and of effectiveness of measures. An important precondition for a rational adaptive behavior is the knowledge about the environmental changes and their effects. The existence of irrational behavior in reality is admitted (due to myopic behavior and other non-economic barriers as presented earlier in this paper), but the economic analysis is mostly based on the assumption of rational behavior in order to base on a clear and consistent theoretical ground.

Regarding mitigation, private voluntary activities like the analyzed adaptation measure (4) cannot be explained in a purely economic framework based on the paradigm of the homo oeconomicus. For any individual, the incentives of no contribution exceed the individual's benefits of contributing to the public good of climate protection (as explained in another context by Hardin, 1968: "The tragedy of the commons"). However, there have been various attempts to explain voluntary contributions to public goods. The most important are the introduction of (impure) altruism (Andreoni, 1988 and 1990), inequity aversion (Fehr and Schmidt, 1999), and reciprocity (Sugden, 1984). Particularly important for individual mitigation in a devel- 
oped country like Germany might be another stream of literature including Elster (1989), Holländer (1990), Ostrom (2000) and Levin (2009). These scholars raise the relevance of social norms and social approval in individual action. Ostrom (2009) is another contribution to the discussion of individual mitigation. The Nobel laureate has presented a polycentric approach which raises the weaknesses of a single global mitigation policy and speaks in favor of policies at multiple levels, from global down to the individual. However, well-known problems of non-global solutions such as carbon leakage and free-riding are highlighted - but sustainable, feasible solutions are not in sight.

The main point here is that economists see very different motivation processes in both strands of behavioral change, leading to the expectation of different determining factors for adaptation and mitigation. In the light of these thoughts, the results presented in Table 2 (for testing hypothesis 1) deserve new attention. It was found that personal perceived risk has a positive influence on the motivation to adapt, whereas four different adaptation measures in a broader sense were examined. Although measures (3) and (4) can obviously be interpreted as mitigation without any direct benefit for the individual, and measure (2) may at least partly be understood as costly mitigation, there is a significant positive influence of risk perception on the willingness to engage in these altruistic behaviors. Following the pure economic theory, this would not be expected since the economic incentives for mitigation do not change with a higher perceived risk, given the negligible influence of a single individual on the global climate. This aspect may become relevant in the context of promotion for climate-friendly behavior. Promoting private mitigation may include a component targeting on the personal perceived risk of people.

Another aspect within the results in Table 2 is the influence of the variable "Interest for climate change". It is positive and significant for measures (3) and (4), which can be interpreted as more altruistic than measure (1) and (2). This means, people who see climate change as a topic worthy of their interest, rather invest in climate protection more than others. This is in line with economic theory, which would suggest looking for reasons other economic motivation for the engagement in private mitigation.

In an economic framework, one important role of the state is to ensure that information about climate change effects is distributed effectively among the exposed population (Dannenberg et al., in press). The assumption is that if private decision makers know about the threat the demand for appropriate adaptation goods will increase up to the point where the marginal costs equal the marginal benefits. In this case the state does not have to intervene unless there

\footnotetext{
${ }^{8}$ Note that we are referring only to autonomous adaptation. In contrary, collective or planned adaptation faces
} 
are no external effects or other well-defined rationales for an intervention. In particular, it would not be necessary and can even be harmful to give very concrete information on specific adaptation techniques. The state should rather stick to more general information on climate change and its effects. In contrast to this theoretical consideration, this survey cannot confirm that pure information about climate impacts is sufficient to increase personal perceived risk and thereby motivation to adapt to new climatic conditions. In particular, hypothesis 2 - stating that the provision of information about expected climate impacts increases the personal perceived risk - could not be supported by the data. Consequently, additional policy options beyond the pure dissemination of information are proposed in the preceding section, such as giving concrete advices on coping measures.

\section{Conclusion}

In light of the expected climatic changes that individuals, communities and organizations will be confronted with in the coming decades, a sound knowledge of these expected impacts and the necessary adaptive responses can be important for their current and future wellbeing. While adaptation is becoming a topic of increasing importance, there has been limited research examining the factors that bolster or hinder motivation to adapt, an important precondition of actually undertaking adaptive measures. Psychological models looking into the processes that occur in decision making under uncertainty could provide insights into this issue. One of these models, Protection Motivation Theory (PMT), is analyzed in more detail in the current research.

Essentially, the findings of this study are first, that personal perceived risk (PPR) has a positive influence on motivation to adapt, though this influence explains only a small share of observed variance. This could be due to other important variables such as the lack of behavioral advice, which may affect coping appraisal, or barriers to behavioral change such as social norms. Hence, the PPR is an important determinant of motivation to adapt but not the only one. Second, we find that the provision of information on possible climate impacts, irrespective of its global or local focus does not show a significant influence on PPR. Nevertheless, other effects (e.g. of gender, revealed knowledge and previous experience) were found to have an influence on PPR. Finally, the provision of local information also did not have a significant effect on PPR compared to the provision of globally focused information, which may be explained by a trade-off between the spatial-temporal distance and the severity of the 
communicated effects: while the local information was more personally relevant for the survey participants, its relatively low severity did not cause a significant increase in perceived risk.

From an economic viewpoint it is noteworthy that although some of the examined adaptation measures were not in the economic self-interest of the individuals the influence of PPR persists even for those measures. This shows that - contrary to standard economic theory - individual mitigation activities are partly determined by PPR. Furthermore, the missing impact of general information on PPR casts doubt about the sufficiency of informing private agents about climate effects and highlights the need to investigate other determinants not considered in the standard economic approach. These are mainly psychological factors influencing the risk perception and ultimately adaptation behavior, such as a low coping appraisal, denial of the threat, or other heuristics discussed in section 2.

These findings address the challenges faced in the design and implementation of information campaigns about climate change adaptation. Though information may be an essential starting point for increasing awareness, many other influencing factors such as socio-cognitive barriers must be considered in increasing perceived risk and ultimately instigating adaptive behavior (Moser and Dilling, 2004). Changing well-established behaviors is likely to require institutional and community mediation in order to provide social contexts and support for behavioral change to take place (Henry and Gordon, 2003).

Further research may look into coping appraisal as another determinant of motivation to adapt, especially into the role of providing concrete explanations of adaptation measures. Moreover, as the low severity of effects in the city of Mannheim and Germany appeared to be an important issue in our study, it may be interesting to replicate this study in a context where effects are likely to be more severe and individuals expect to be more vulnerable. 


\section{References}

Adger, N. (2001) Scales of Governance and Environmental Justice For Adaptation and Mitigation of Climate Change. Journal of International Development 13, 921-931.

Adger, W. N., Dessai, S., Goulden, M., Hulme, M., Lorenzoni, I., Nelson D. R., Naess, L. O. Wolf, J. and Wreford, A. (2009) Are There Social Limits to Adaptation to Climate Change? Climatic Change 93, 335-354.

Andreoni, J. (1988) Privately provided Public Goods in a Large Economy: The Limits of Altruism. Journal of Public Economics 35, 57-73.

Andreoni, J. (1990) Impure Altruism and Donations to Public Goods: A Theory of WarmGlow Giving. The Economic Journal 100, 464-477.

Bosello, F., Carraro, C. and de Cian, E. (2009) An Analysis of Adaptation as a Response to Climate Change. Working Paper No. 25/2009, Department of Economics, University of Venice.

Chan, J. C. (1996) Estimating the Latent Trait from Likert-type Data: A Comparison of Factor-Analysis, Item Response Theory, and Multidimensional Scaling. The Journal of National Chengchi University 72, 299-320.

Ciscar, J. C. (editor) (2009). Climate Change Impacts in Europe, Final Report of the PESETA Research Project.

Dannenberg, A., Mennel, T., Osberghaus, D. and Sturm, B. (in press) The Role of the Government in Adaptation to Climate Change, Environment and Planning C.

de Bruin, K. C., Dellink, R. B. and Tol, R. S. J. (2009) AD-DICE: an implementation of adaptation in the DICE model. Climatic Change 95, 63-81.

Elster, J. (1989) Social Norms and Economic Theory. Journal of Economic Perspectives 3, No. 4, 99-117. 
Etkin, D. and Ho, E. (2007) Climate Change: Perceptions and Discourses of Risk. Journal of Risk Research 10, No. 5, 623-641.

Fehr, E. and Schmidt, K. M. (1999) A Theory of Fairness, Competition, and Cooperation. The Quarterly Journal of Economics, August 1999, 817-868

Floyd, D. L, Prentice-Dunn, S. and Rogers, R. W. (2000) A Meta-Analysis of Research on Protection Motivation Theory, Journal of Applied Social Psychology, 30, No. 2, 407-429.

Fankhauser, S. and Tol, R. S. J. (1997) The Social Costs of Climate Change: The IPCC Second Assessment Report and Beyond. Mitigation and Adaptation Strategies for Global Change 1, 385-403.

Lorenzoni, I. and Hulme, M. (2009) Believing is seeing: laypeople's views of future socioeconomic and climate change in England and Italy. Public Understanding of Science 18, 383400.

Grothmann, T. and Patt, A. (2005) Adaptive capacity and human cognition: The process of individual adaptation to climate change. Global Environmental Change 15, 199-213.

Grothmann, T. and Reusswig F. (2006), People at Risk of Flooding: Why Some Residents Take Precautionary Action While Others do not. Natural Hazards 38, 101-120.

Hardin, G. (1968) The Tragedy of the Commons. Science 162, 1243-1248.

Henry, G. T. and Gordon, C. S. (2003) Driving Less for Better Air: Impacts of a Public Information Campaign. Journal of Policy Analysis and Management 22, No. 1, 45-63.

Holländer, H. (1990) A Social Exchange Approach to Voluntary Cooperation. The American Economic Review 80, No. 5, 1157-1167.

IPCC, 2007a: Climate Change (2007): The Physical Science Basis. Contribution of Working Group I to the Fourth Assessment Report of the Intergovernmental Panel on Climate Change 
[Solomon, S., Qin, D., Manning, M., Chen, Z., Marquis, M., Averyt, K. B., Tignor, M. and Miller, H. L. (eds.)]. Cambridge University Press, Cambridge, United Kingdom and New York, NY, USA, 996 pp.

IPCC, 2007b, Climate Change 2007: Impacts, Adaptation and Vulnerability. Contribution of Working Group II to the Fourth Assessment Report of the Intergovernmental Panel on Climate Change Parry, M. L., Canziani, O. F., Palutikof, J. P., van der Linden, P. J., Hanson, C. E. (eds.). Cambridge University Press, Cambridge, UK, 976 pp.

IPCC, 2007c: Summary for Policymakers. In: Climate Change 2007: Impacts, Adaptation and Vulnerability. Contribution of Working Group II to the Fourth Assessment Report of the Intergovernmental Panel on Climate Change, Parry, M. L., Canziani, O. F., Palutikof, J. P., van der Linden, P. J., Hanson, C. E. (eds.). Cambridge University Press, Cambridge, UK, 7-22.

Jaccard, J. and Wan, C. K. (1996) LISREL Approaches to Interaction Effects in Multiple Regression, Series: Quantitative Applications in the Social Sciences, SAGE University Paper.

Kellstedt, P. M., Zahran, S. and Vedlitz, A. (2008) Personal Efficacy, the Information Environment, and Attitudes Toward Global Warming and Climate Change in the United States. Risk Analysis 28, No. 1, 113-126.

Klein, R. J. T., Nicholls, R. T. and Mimura, N. (1999) Coastal Adaptation to Climate Change: Can the IPCC Technical Guidelines be Applied? Mitigation and Adaptation Strategies for Global Change 4, 239-252.

Kunreuther, H. (1996) Mitigating Disaster Losses through Insurance. Journal of Risk and Uncertainty $12,171-187$.

Kroemker, D. and Mosler, H. J. (2002) Human Vulnerability - Factors Influencing the Implementation of Prevention and Protection Measures: An Agent based Approach, Global Environmental Change in Alpine Regions: Recognition, Impact, Adaptation and Mitigation, Edward Elgar Publishing, Inc., 93-112. 
Leiserowitz, A. (2006) Climate Change Risk Perception and Policy Preferences: The Role of Affect, Imagery and Values. Climatic Change 77, 45-72.

Leiserowitz, A. (2007) Public Perception, Opinion and Understanding of Climate Change: Current Patterns, Trends and Limitations. New York: United Nations Development Programme.

Levin, S. A. (2009) Games, Groups, Norms, and Societies. In Games, Groups, and the Global Good, ed. S. A. Levin. Berlin; London: Springer. 143-153.

Mendelsohn, R. (2000) Efficient Adaptation to Climate Change. Climatic Change 45, No. 3-4, 583-600.

Miller, S. (2001) Public Understanding of Science at the Crossroads, Public Understanding of Science 10, 115-120.

Moser, S. C. and Dilling, L. (2007) Toward the social tipping point: creating a climate for change, in: Creating a Climate for Change: Communicating Climate Change and Facilitating Social Change, Cambridge University Press, 491-516.

Nisbet, M. C. and Myers, T. (2007) The Polls-Trends: Twenty Years of Public Opinion About Global Warming. Public Opinion Quarterly 71, No. 3, 444-470.

Norgaard, K. M. (2006) "People Want to Protect Themselves a Little Bit": Emotions, Denial and Social Movement Nonparticipation. Sociological Inquiry 76, No. 3, 372-396.

Norman, P., Boer, H., and Seydel, E. R. (2005) Protection motivation theory. In: Predicting Health Behaviour: Research and Practice with Social Cognition Models. Open University Press, Maidenhead, pp. 81-126.

Ostrom, E. (2000) Collective Action and the Evolution of Social Norms. Journal of Economic Perspectives 14, No. 3, 137-158. 
Ostrom, E. (2009) A Polycentric Approach for Coping with Climate Change. Policy Research Working Paper 5095, The World Bank.

Papke, L. E. and Wooldridge, J. M. (1996) Econometric Methods for Fractional Response Variables with an Application to 401(k) Plan Participation Rates. Journal of Applied Econometrics 11, 619-632.

Rogers, R. W. (1975) A Protection motivation theory of fear appeals and attitude change, Journal of Pschology 91, 93-114.

Rogers, R. W. and Maddux, J. E. (1983) Protection Motivation and Self-Efficacy: A Revised Theory of Fear Appeals and Attitude Change. Journal of Experimental and Social Psychology $19,469-479$.

Rogers, R. W. and Prentice-Dunn, S. (1997). Protection motivation theory, In: Gochman, D. S. (Eds.), Handbook of Health Behavior Research. I: Personal and Social Determinants (pp. 113-132). New York, NY: Plenum.

Schultz, P. W., Nolan, J. M., Cialdini, R. B., Goldstein, N. J. and Griskevicius, V. (2007) The Constructive, Destructive, and Reconstructive Power of Social Norms. Psychological Science 18, No. 5, 429-434.

Smit, B. and O. Pilifosova. 2003. From adaptation to adaptive capacity and vulnerability reduction. In J. Smith, R. T. J. Klein and S. Huq (eds.), Climate Change, Adaptive Capacity and Development. London: Imperial College Press, 9-28.

Smit, B. and Wandel, J. (2006) Adaptation, Adaptive Capacity and Vulnerability. Global Environmental Change 16, 282-292.

Stern, N. (2007), The Economics of Climate Change: The Stern Review. Cambridge University Press.

Sturgis, P. and Allum, N. (2004) Science in Society: Re-Evaluating the Deficit Model of Public Attitudes. Public Understanding of Science 13, 55-74. 
Sugden, R. (1984) The Supply of Public Goods through Voluntary Contributions. The Economic Journal 94, No. 376, 772-787.

Tol, R. S. J. (2005) Adaptation and mitigation: trade-offs in substance and methods. Environmental Science and Policy 8, No. 6, 572-578.

Weisskopf, M. G., Anderson, H. A., Foldy, S., Hanrahan, L. P., Blair, K., Török, T. J. and Rumm, P. D. (2002) Heat Wave Morbidity and Mortality, Milwaukee, Wis, 1999 vs. 1995: An Improved Response? American Journal of Public Health 92, No.5, 830-833.

Wilbanks, T. J. (2003) Integrating Climate Change and Sustainable Development in a PlaceBased Context. Climate Policy 3, Sup. 1, 147-154.

Wolf, J., Adger, W. N., Lorenzoni, I., Abrahamson, V., and Raine, R. (2010) Social Capital, Individual Responses to Heat Waves and Climate Change Adaptation: An empirical study of two UK cities. Global Environmental Change 20, 44-52.

World Development Report (2010) Overcoming Behavioral and Institutional Inertia. World Development Report 2010, Washington DC: The World Bank.

Wright, N. and Nerlich, B. (2006) Use of the Deficit Model in a Shared culture of Argumentation: the Case of Foot and Mouth Science. Public Understanding of Science 15, 331-342. 